Prepared in Cooperation with the

Pennsylvania Department of Transportation

Phase 1 Freshwater Mussel Survey and Comparison to Historical Surveys at the Pond Eddy Bridge, Delaware River, New York and Pennsylvania

Open-File Report 2012-1224 



\section{Phase 1 Freshwater Mussel Survey and Comparison to Historical Surveys at the Pond Eddy Bridge, Delaware River, New York and Pennsylvania}

By Heather S. Galbraith

Prepared in cooperation with the

Pennsylvania Department of Transportation

Open-File Report 2012-1224 


\section{U.S. Department of the Interior \\ KEN SALAZAR, Secretary \\ U.S. Geological Survey \\ Marcia K. McNutt, Director}

\section{U.S. Geological Survey, Reston, Virginia: 2012}

For more information on the USGS - the Federal source for science about the Earth, its natural and living resources, natural hazards, and the environment, visit http://www.usgs.gov or call 1-888-ASK-USGS.

For an overview of USGS information products, including maps, imagery, and publications, visit http://www.usgs.gov/pubprod

To order this and other USGS information products, visit http://store.usgs.gov

Any use of trade, product, or firm names is for descriptive purposes only and does not imply endorsement by the U.S. Government.

Although this report is in the public domain, permission must be secured from the individual copyright owners to reproduce any copyrighted materials contained within this report.

Suggested citation:

Galbraith, H.S., 2012, Phase 1 freshwater mussel survey and comparison to historical surveys at the Pond Eddy bridge, Delaware River, New York and Pennsylvania: U.S. Geological Survey Open-File Report 2012-1224, 17 p. 


\section{Contents}

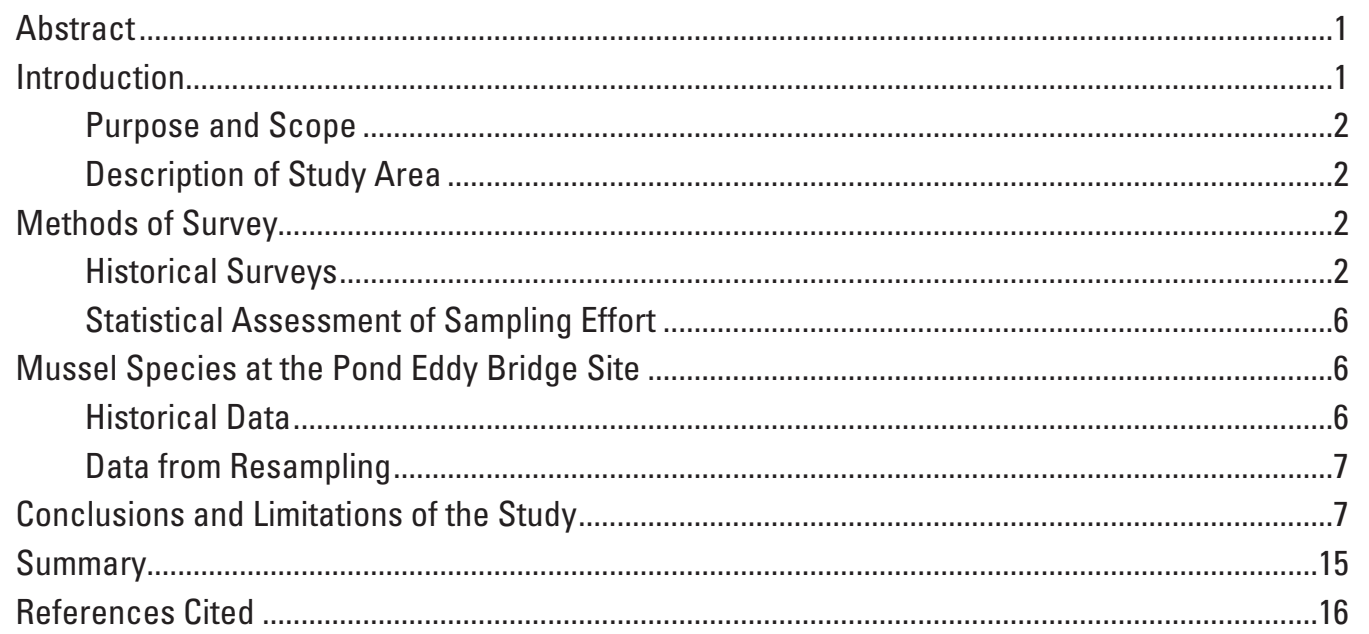




\section{Figures}

1. Map showing Pond Eddy Bridge site located at the main stem upper Delaware River between New York and Pennsylvania.

2. Maps showing catch per unit effort of $A, A$. implicata, $B, S$. undulatus, $C, E$. complanata, and D, total mussel count for each 25-meter x 25-meter cell at the Pond Eddy Bridge site, New York and Pennsylvania, 2011

3. Blueprint showing proposed construction plans for the new Pond Eddy Bridge between New York and Pennsylvania

4. Maps showing statistically significant clusters of high and low catch per unit effort values, and outlier catch per unit effort values in which high values are surrounded by low values and low values are surrounded by high values for selected mussel species, Pond Eddy Bridge site, New York and Pennsylvania, 2011.

5. Boxplots of selected mussel species CPUE and community metrics obtained by statistically resampling 400-meter sections of the upper Delaware River sampled in 2001 in relation to data collected at the Pond Eddy Bridge site, New York and Pennsylvania, in 2011

6. Boxplots of selected mussel species CPUE and community metrics obtained by statistically resampling data from cells at the Pond Eddy Bridge site, New York and Pennsylvania, 2011.

7. Graphs showing relation of percent of cells to the mean values for six community metrics obtained from statistical resampling at the Pond Eddy Bridge site, New York and Pennsylvania, 2011.

8. Graphs showing variance of mussel species and selected community metrics obtained from statistical resampling in relation to the percent of cells at the Pond Eddy Bridge site, New York and Pennsylvania, 2011

9. Map showing estimated zone of impact of new bridge construction and mussel Anodonta implicata, in catch per unit effort, at the Pond Eddy Bridge site, New York and Pennsylvania, 2011. 


\section{Tables}

1. Catch per unit effort (CPUE) and percentage of all individuals for three species of mussels from the Delaware River at the Pond Eddy Bridge site, New York and Pennsylvania

2. Results of linear and segmented regression analysis on community metrics generated from statistical resampling and calculated at different sampling efforts for the 2011 survey at Pond Eddy Bridge site, New York and Pennsylvania

\section{Conversion Factors}

\begin{tabular}{lcl}
\multicolumn{1}{c}{ SI to Inch/Pound } & & \\
\hline \multicolumn{1}{c}{ Multiply } & By & To obtain \\
\hline meter $(\mathrm{m})$ & Length & \\
kilometer $(\mathrm{km})$ & 3.281 & foot $(\mathrm{ft})$ \\
\end{tabular}





\title{
Phase 1 Freshwater Mussel Survey and Comparison to Historical Surveys at the Pond Eddy Bridge, Delaware River, New York and Pennsylvania
}

\author{
By Heather S. Galbraith
}

\begin{abstract}
A qualitative freshwater mussel survey was conducted in a section of the main stem Delaware River near the Pond Eddy Bridge site, New York and Pennsylvania, during summer 2011 to assess population levels of state and Federal threatened and endangered species. Historical data that were collected at this site were compared to data from the 2011 survey to assess changes in mussel community composition and differences in survey methodology. A total of 4,080 mussels of three species-Elliptio complanata, Anodonta implicata, and Strophitus undulatus - were sampled at the Pond Eddy Bridge site in 2011. No mussel species (Alasmidonta heterodon or Alasmidonta varicosa) that are on Federal or state lists of threatened or endangered species or their shells were collected in this survey. These results are comparable to historical surveys at the site, with some differences in estimated catch per unit effort (CPUE) and species detection, depending upon survey methodology. The CPUE of the three species and species richness and diversity were evaluated. The percentages of species composition for A. implicata, E. complanata, and S. undulatus were $0.02,0.97$, and 0.002 , respectively, in 2011 .
\end{abstract}

\section{Introduction}

Freshwater mussels are a highly imperiled fauna with greater than 70 percent of species in North America considered vulnerable (Williams and others, 1993; Lydeard and others, 2004). Mussels perform a variety of important ecological services, and there has been a surge of interest in their conservation (Vaughn, 2010). Mussels are threatened by a variety of anthropogenic disturbances, including contaminants, invasive species (for example, zebra mussels), and habitat loss and modification (Strayer, 1999; Watters, 2000). Construction activities in or near water bodies can have substantial effects on freshwater mussels through hydrologic alterations and siltation (Neves and others, 1997; Watters, 2000). Incidental loss of mussels can result directly from construction efforts or indirectly by habitat alteration in the immediate vicinity of construction sites (Smith and others, 2001). Therefore, prior to major construction activities, mussel surveys for rare or threatened species are conducted to determine where minimization and mitigation efforts can reduce the impact on species listed as threatened or endangered.

Survey techniques for freshwater mussels vary considerably depending upon system, spatial scale, and community metric of interest. Qualitative surveys are often used to assess species richness and diversity because typically more individuals are sampled (and thus more species); however, qualitative surveys can be biased towards finding large, sculptured, or surface-dwelling species (Miller and Payne, 1993; Vaughn and others, 1997; Dorazio, 1999). Alternatively, quantitative sampling is often used for estimates of mussel density, recruitment, and population demographics but can be time consuming (therefore, expensive) and an inefficient means of detecting rare species (Miller and Payne, 1993; Dorazio, 1999 ). Rare species detection can be particularly important in assessing potential impacts of anthropogenic disturbance on mussel communities; however, studies of basic mussel ecology or long-term monitoring of broader community characteristics, such as richness or density, may be more relevant. Therefore, there is a tradeoff in sampling design depending on the primary focus of the study. Standardized sampling methods are often considered important for quality control and comparison among survey locations (Smith and others, 2001; Huang and others, 2011). Many management agencies are developing standardized survey protocols for freshwater mussels; however, few studies have assessed the repeatability of standardized survey methods (Huang and others, 2011). This study was conducted to assess changes in the mussel communities and evaluate survey methods.

In September 2001, a Phase 1 survey for dwarf wedgemussel (Alasmidonta heterodon) was conducted near the Pond Eddy Bridge at which time no individuals of this species were found (Normandeau Associates, 2002). Only the eastern elliptio (Elliptio complanata) and alewife floater (Anodonta implicata) individuals were identified at this site. Additionally, Lellis $(2001,2002)$ completed qualitative surveys in this area starting in the summer of 2000 while conducting an independent survey of the Delaware River main stem. During this 
Phase 1 Freshwater Mussel Survey and Comparison to Historical Surveys at Pond Eddy Bridge, Delaware River, N.Y. and Pa.

qualitative survey no listed mussel species were found at the Pond Eddy Bridge; however, a single brook floater (Alasmidonta varicosa) was detected approximately 450 meters (m) upstream from the bridge.

Surveys of freshwater mussel are considered valid by the U.S. Fish and Wildlife Service for 3 to 5 years, after which species distributions and abundance may change (Robert Anderson, U.S. Fish and Wildlife Service, written commun., 2011). Therefore, U.S. Fish and Wildlife Service recommended that the 2000/2001 mussel surveys be repeated to validate the assumption that the dwarf wedgemussel is still absent from this site and to confirm that no other Federal or state listed species are present at the Pond Eddy Bridge location. The U.S. Geological Survey, in cooperation with the Pennsylvania Department of Transportation (PennDOT), conducted a study in 2011 to resurvey the Pond Eddy bridge site to document threatened or endangered species. Given that repeated, high-resolution freshwater mussel data are sparse, the survey results were compared to the results from the early 2000s, and the sampling effort necessary to adequately estimate mussel community structure at a typical reach within the upper Delaware River was evaluated.

\section{Purpose and Scope}

This report presents the results of a repeat survey of the mussel community in the Delaware River at Pond Eddy Bridge site conducted in 2011. Mussel data from 2011 are compared with data from the early 2000s. The sampling effort necessary for estimating community characteristics for Delaware River mussel beds is discussed.

\section{Description of Study Area}

The Delaware River is the longest undammed river east of the Mississippi. It flows through and serves as a boundary between Delaware, New York, New Jersey, and Pennsylvania (fig. 1). Historically, the Delaware River contained 12 to 14 species of freshwater mussels including several populations of federally listed, endangered A. heterodon (Ortmann, 1919; Lellis, 2001). Populations of $A$. varicosa, listed by the State of New York as threatened and endangered, and the critically imperiled (but unlisted) A. implicata have also been found in the Delaware River (Lellis 2001, 2002). PennDOT is planning to replace the bridge crossing the upper Delaware River from Pond Eddy, N.Y. (Sullivan County) to Pond Eddy, Pa., at an upstream site (Pike County; fig. 1).

\section{Methods of Survey}

Phase 1 of the Pond Eddy mussel survey was conducted from August 15 to September 23 of 2011. Survey crews consisted of four to six people. Qualitative sampling in the main stem Delaware River extended bank to bank $200 \mathrm{~m}$ downstream from the existing Pond Eddy Bridge to $50 \mathrm{~m}$ upstream from the confluence of Mill Brook for a total stretch of river just under $400 \mathrm{~m}$ in length (fig. 2). An additional $50 \mathrm{~m}$ was surveyed upstream in Mill Brook starting at the confluence with the main stem. Using methods described by Smith and others (2001), the river was divided into a series of $25-\mathrm{m}$ by $25-\mathrm{m}$ cells, and each cell was searched for a total of 2 working hours (a working hour is equivalent to one person working for 1 hour; fig. 2). In some cases, cells were searched for less than 2 working hours if they included dry bank or if they were primarily bedrock (substrate generally uninhabitable for freshwater mussels). In these instances, the percentage of the cell that was surveyable was approximated, and survey time was adjusted accordingly (for example, if only $75 \%$ of the cell was underwater, it was searched for a total of 90 minutes). In each cell, the substrate surface was intensively searched by persons using snorkeling gear, SCUBA gear, or a combination of both. All mussels were identified by species, counted, and recorded. In addition, mussel middens along the banks on both sides of the river were searched for shells of listed species. After completing the survey, total mussel catch per unit effort (CPUE) was calculated, as was CPUE for each species, each species as a percentage of the total count, richness, and diversity (inverse Simpson's index, 1/D (Hill, 1973)).

ArcGIS was used to map the mussel community composition of each cell at the Pond Eddy Bridge site. Cluster and outlier analysis (Anselin Local Morans I analysis (Anselin, 1995)) was used to determine where clusters of each species were significantly higher (or lower) than predicted on the basis of populations in the neighboring cells.

The predicted impact the impending bridge replacement would have on the freshwater mussel community was assessed using blueprints provided by Skelly and Loy, Inc. (fig.3). The current plans for bridge construction will locate the new, 9-m

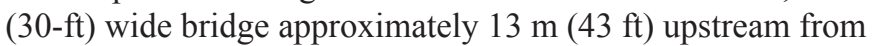
the standing Pond Eddy Bridge. A temporary causeway will be constructed upstream from the new bridge, although the exact location of the causeway has not yet been determined. Skelly and Loy, Inc., estimated that the zone of temporary impact would constitute a section of river approximately $46 \mathrm{~m}(150 \mathrm{ft})$ long upstream to downstream, across the entire width of the river (about $162 \mathrm{~m}$ or $530 \mathrm{ft}$ ). For the purposes of this report, the zone was assumed to center on the new bridge. Given that the causeway location and the number and location of the support piers are not yet precisely defined, the 46-m width of the estimated impact zone includes a substantial buffer. However, all direct effects of the bridge replacement project will occur within this zone, which is approximately $46 \mathrm{~m}$ by $162 \mathrm{~m}$.

\section{Historical Surveys}

Lellis $(2001,2002)$ conducted mussel surveys along 230 kilometers $(\mathrm{km})$ of the upper Delaware River from Hancock, N.Y., to Portland, Pa., in 2000 and 2001. Five to eight surveyors snorkeled approximately $200-\mathrm{m}$ straight line 


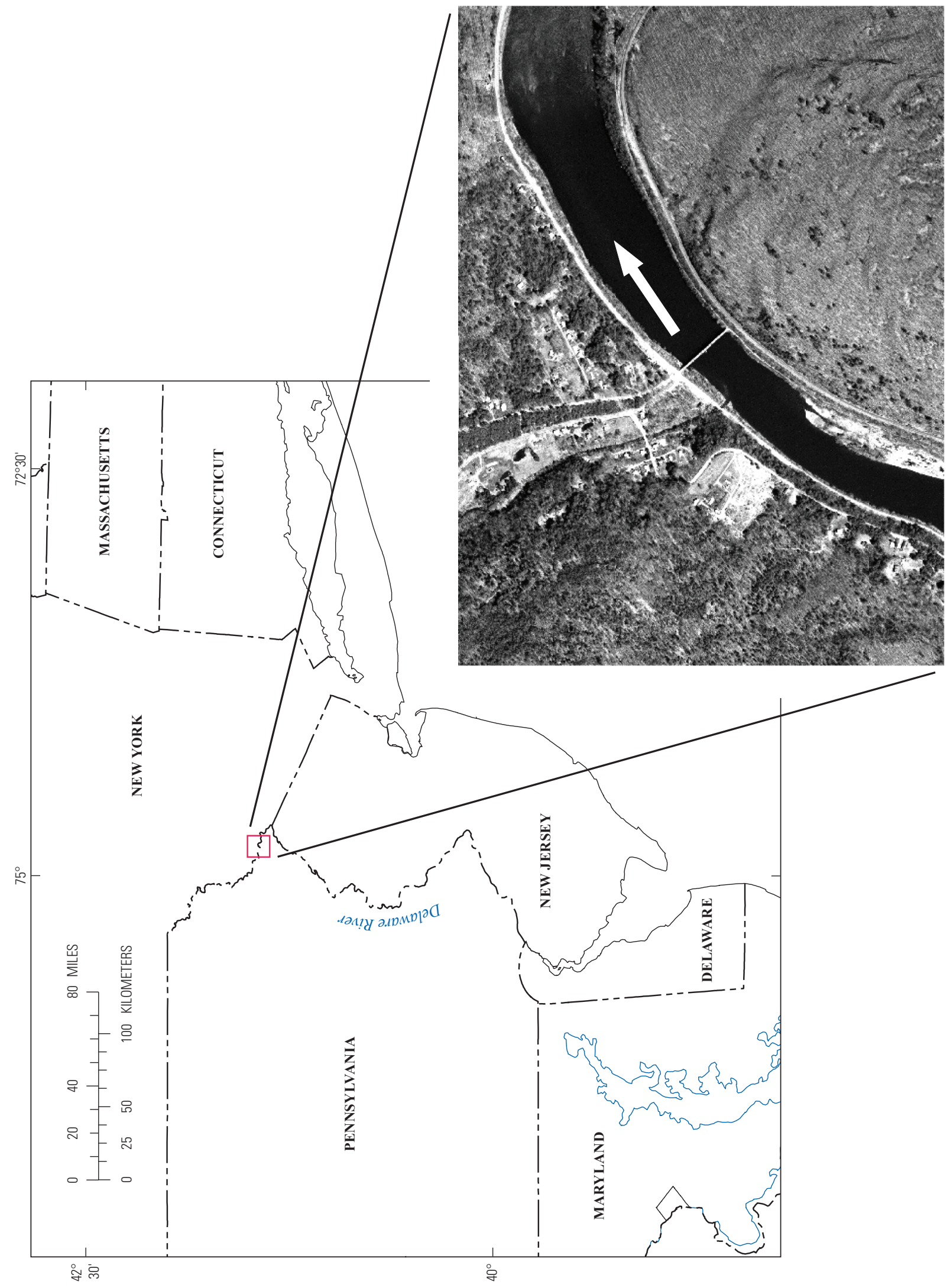

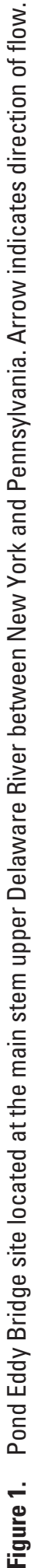



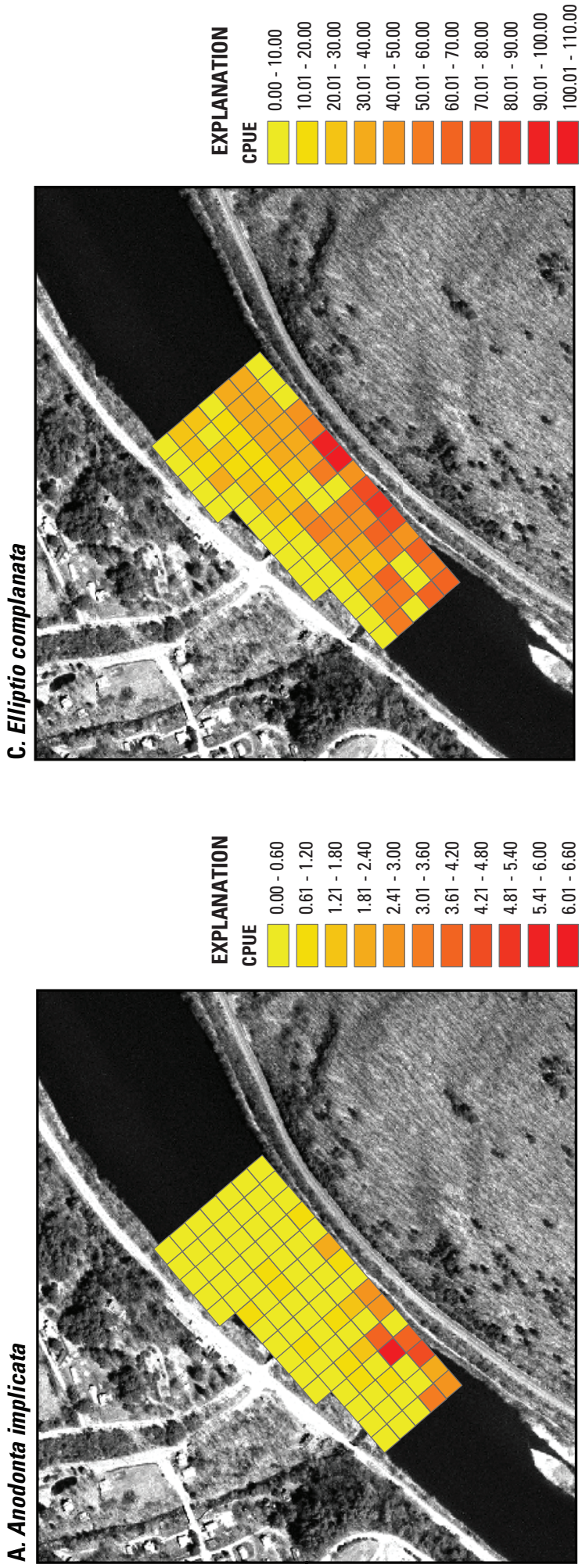
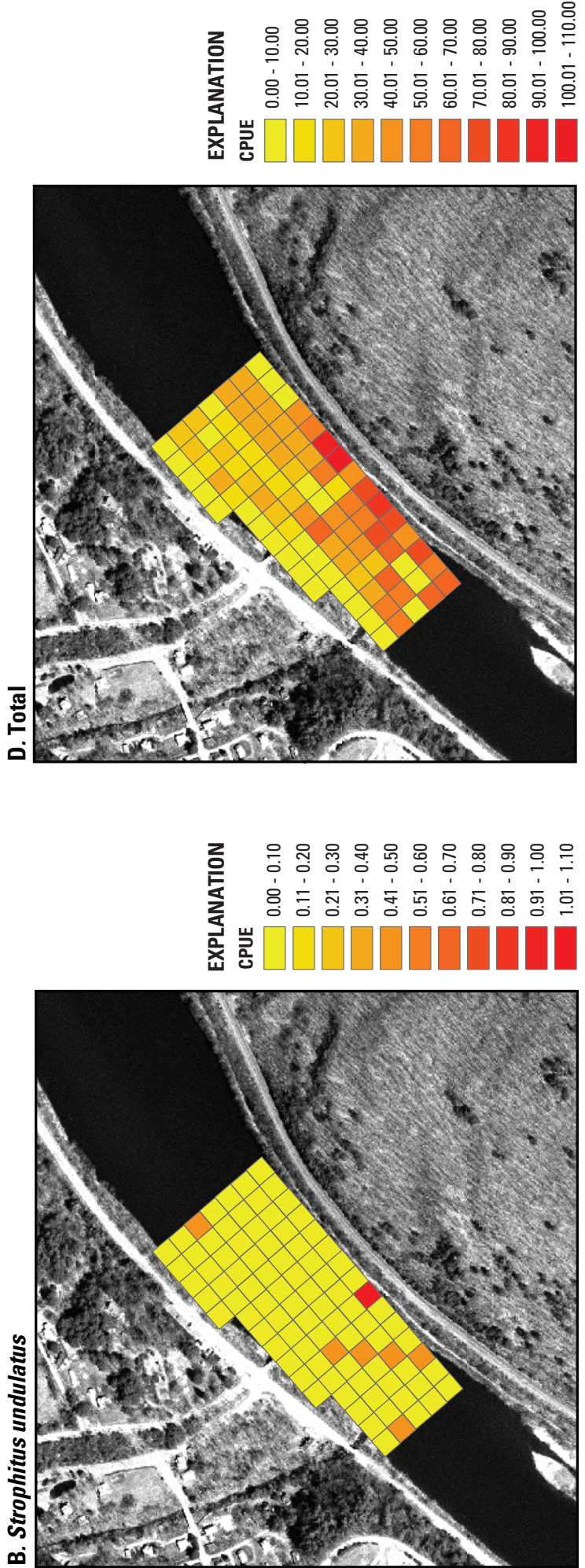

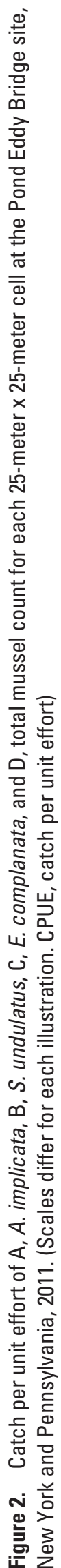




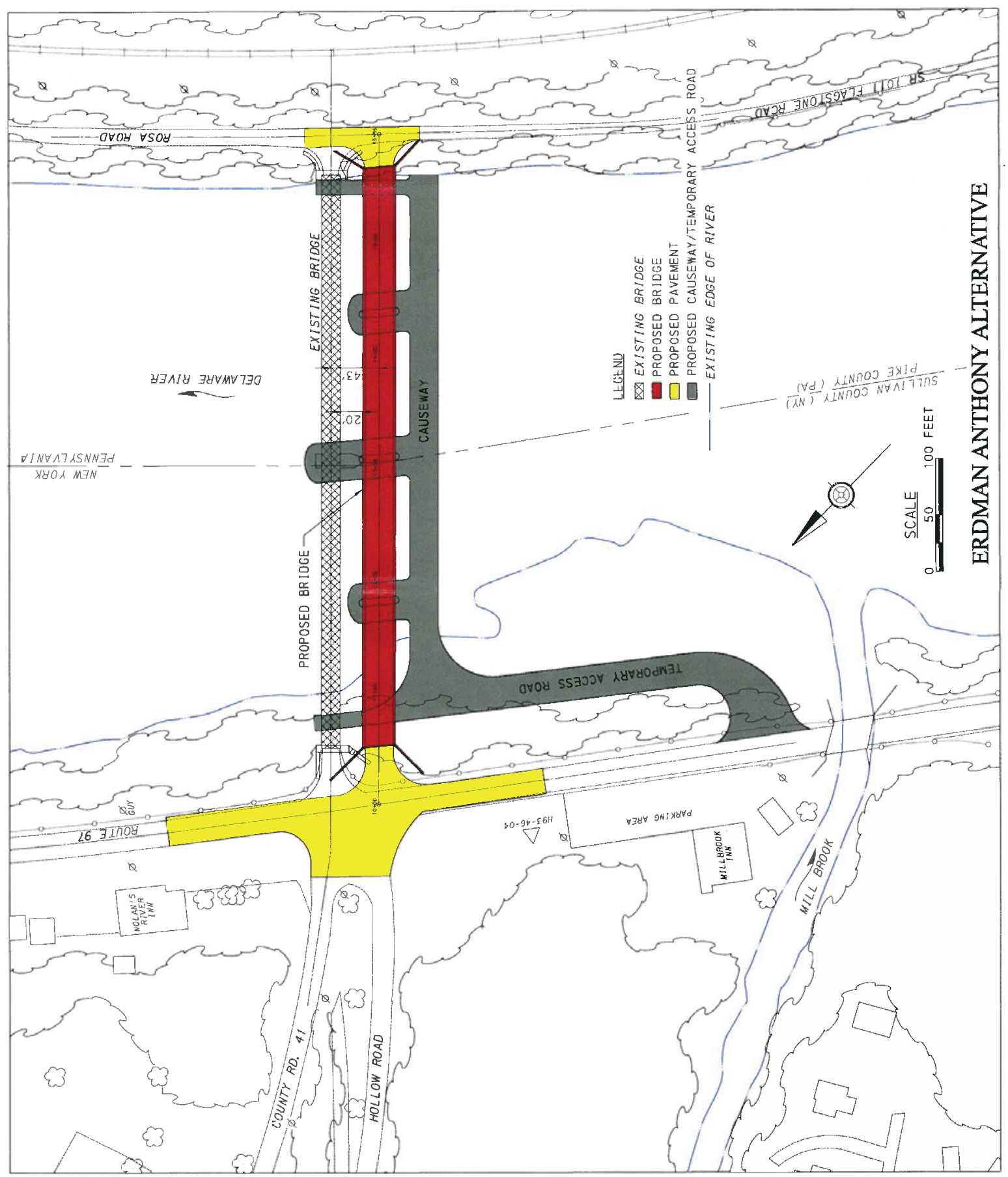


Phase 1 Freshwater Mussel Survey and Comparison to Historical Surveys at Pond Eddy Bridge, Delaware River, N.Y. and Pa.

transects (hereafter referred to as sections) from upstream to downstream for target coverage of 10 to 15 search hours per $1.6 \mathrm{~km}$ of river. Unique habitats, backwaters, eddies, and pools less than $10 \mathrm{~m}$ deep were searched. At the end of each section, all mussels were identified, counted and recorded (Lellis 2001, 2002). During the 2000 sampling, the area from the main stem Delaware River/Mill Brook confluence to the Pond Eddy Bridge was surveyed, as was the area from the bridge $200 \mathrm{~m}$ downstream. This roughly corresponds to the section of river assessed in the 2011 survey. Community metrics (described above) were calculated for the 2000/2001 surveys and compared to metrics from the present study.

Normandeau Associates, Inc., completed a survey at the Pond Eddy Bridge site in 2001 as part of the bridge replacement project (Normandeau Associates 2002). The methods used were identical to those described for the present study; however, the extent of this survey included qualitatively surveying only 48 cells, about half of the cells in the current survey, for 2 working hours each. Water levels in 2001 were substantially lower than in 2011. At the USGS streamgaging station in Callicoon, N.Y. (site number 01427510), mean discharge ( \pm standard deviation (SD)) in 2001 during surveying was $32.6( \pm 1.0)$ cubic meters per second $\left(\mathrm{m}^{3} / \mathrm{s}\right) ; 2011$ discharge was $76.0 \mathrm{~m}^{3} / \mathrm{s}( \pm 17.4)$. This may account for the lower number of cells surveyed in 2001. Additionally, the 2001 survey extended $100 \mathrm{~m}$ upstream from the bridge, whereas the 2011 survey extended approximately $175 \mathrm{~m}$ upstream from the bridge. The report by Normandeau Associates, Inc., does not explicitly present catch per unit effort (CPUE) data but does present raw numbers of individuals. Therefore, CPUE was calculated by assuming that all 48 cells were searched for the entire 2 working hours to compare the 2001 survey to the 2011 survey (Normandeau Associates, Inc., 2002). Species richness and diversity (inverse Simpson's index) were calculated to compare the Lellis (2001) survey and the 2011 survey.

\section{Statistical Assessment of Sampling Effort}

All statistical procedures were completed using the statistical software R (R Development Core Team, 2011). To assess the sampling effort necessary to estimate community metrics of a typical site in the upper Delaware River, it was first determined whether the Pond Eddy Bridge site was representative of a randomly selected $400 \mathrm{~m}$ stretch of the Delaware River. To do this, random samples of two 200-m sections of the upper Delaware River were obtained from the early 2000's data (Lellis, 2001, 2002) using statistical resampling procedures (Efron, 1979). For each historical sample, a suite of community metrics was calculated: total mussel CPUE, CPUE of individual species, species richness, and diversity. This process was iterated 1,000 times to generate statistical sampling distributions from the historical record and define the 95-percent confidence limit for each metric. Each community metric at the Pond Eddy Bridge site was compared to the sampling distribution from the entire river. If the Pond Eddy metrics fell within the 95-percent confidence limits for the upper Delaware, the Pond Eddy site was assumed to be not significantly different from any other $400-\mathrm{m}$ stretch in the river.

Random samples of 25-m x 25-m cells were drawn (with replacement) from within the Pond Eddy data, ranging from a single cell to 100 percent of all surveyed cells to simulate the entire range of possible sampling efforts at the site. The same community metrics described above were calculated for each random sample, and this process was iterated 1,000 times. This generated a series of statistical distributions for each level of sampling effort (from 1 to $100 \%$ of the cells) and community metric. Sampling effort (as percent of cells surveyed) was plotted in relation to the mean and variance of each metric, and segmented regression was used to determine breakpoints within the distribution. These breakpoints, which indicate the point at which there is a non-constant regression parameter, were used to indicate the sampling effort that approximated the true (that is, population) community metric. It was assumed that a baseline amount of at least 10 percent of the site would be surveyed (because of high variance); therefore, these data points were eliminated. Segmented regression was computed only on samples of greater than 10 percent of the site. Therefore, estimates of the sampling effort needed were calculated above a baseline of 10 percent of the sampling effort. Segmented regression was completed only if a significant linear relationship was first identified.

\section{Mussel Species at the Pond Eddy Bridge Site}

A total of 4,080 mussels of three species-E. complanata, A. implicata, and Strophitus undulatus (table 1) -were collected at the Pond Eddy Bridge site in 2011. No Federal or state listed mussel species (A. heterodon or A. varicosa) or their shells were obtained during this survey, and all mussels were found in the main stem Delaware River (that is, no mussels in Mill Brook). More than 97 percent of all mussels were E. complanata. A. implicata and $S$. undulatus were rare, accounting for approximately 2 percent and less than 1 percent of the mussels, respectively. Mean $( \pm$ SD) CPUE for all mussels combined was approximately 32.44 individuals per hour ( \pm 25.32$)$, but the mean CPUE varied considerably from cell to cell, according to species and location within the river (table 1; fig. 2).

Significant spatial clustering was observed for all species on the Pennsylvania side of the river and specifically the Pennsylvania side upstream from the bridge for A. implicata. All $S$. undulatus, except for a single individual, were found upstream from the bridge (fig. 4). 
Table 1. Catch per unit effort (CPUE) and percentage of all individuals for three species of mussels from the Delaware River at the Pond Eddy Bridge site, New York and Pennsylvania. Comparison of community metrics among three qualitative mussel surveys completed at the Pond Eddy Bridge.

[CPUE, catch per unit effort; USGS, U.S. Geological Survey; \%, percent; SD, standard deviation; N, number of species; Diversity, inverse Simpson's index]

\begin{tabular}{lllcc}
\hline Species & Community metric & \multicolumn{1}{c}{$\begin{array}{c}\text { USGS, } \\
\mathbf{2 0 1 1} \\
\text { (SD) }\end{array}$} & $\begin{array}{c}\text { Lellis, } \\
\mathbf{2 0 0 1}\end{array}$ & $\begin{array}{c}\text { Normandeau } \\
\text { Associates, } \\
\text { Inc., 2002 }\end{array}$ \\
\hline A. implicata & CPUE & $0.66(1.19)$ & 5.85 & 0.24 \\
& \% composition & 0.02 & 0.05 & 0.03 \\
E. complanata & CPUE & $31.73(24.64)$ & 101.95 & 8.10 \\
& \% composition & 0.97 & 0.94 & 0.97 \\
S. undulatus & CPUE & $0.05(0.17)$ & 0.98 & 0.00 \\
& \% composition & 0.002 & 0.01 & 0.00 \\
& Total CPUE & $32.44(25.32)$ & 108.78 & 8.34 \\
& Richness (N) & 3 & 3 & 2 \\
\hline
\end{tabular}

\section{Historical Data}

Data on mussels, by transect, from Lellis (2001) were similar in species richness and percent species composition to the data for the 2011 survey (table 1). However, CPUE values were 2 to 20 times higher than those for 2011, depending on the species, and their estimate of diversity was slightly larger. Normandeau Associates, Inc., found only two (E. complanata and $A$. implicata) of the three species detected in the other two surveys, and the estimated CPUEs were substantially lower (3-4 times lower than those observed in the present study and 12 to 25 times lower than those observed by Lellis (2001)) (Normandeau Associates, Inc., 2002). The percentage of each species (excluding $S$. undulatus) determined by Normandeau Associates, Inc., however, was similar to that of this study and that of Lellis (2001) (table 1).

\section{Data from Resampling}

Data on species richness and percent species composition at the Pond Eddy Bridge site during 2011 fell on or within the 95-percent confidence limits of the entire upper Delaware River for all community metrics (fig. 5), which indicates that the Pond Eddy Bridge site is a typical site in this river; therefore, the bridge site was further assessed for the sampling effort necessary to attain an accurate estimate of mussel community composition. As expected, community metrics closely approximated those of the "true" community (that is, the entire population at Pond Eddy) with increasing sampling effort (fig. 6). Overall, there was little effect of sampling effort on the mean community metrics (figs. 6 and 7); however, the median of all metrics increased towards the population value with increased sampling (fig. 6). Variance decreased with increasing sampling effort for each community metric (fig. 8). Segmented regression analyses identified breakpoints for community metric variance generally near 25 cells (approximately $30 \%$ of the surveyed area), but the percentage of cells varied slightly according to the metric of interest (table 2; figs. 7 and 8 ).

\section{Conclusions and Limitations of the Study}

The 2011 survey results from the Pond Eddy site are consistent with results of previous studies conducted at this location (Lellis, 2001; Normandeau Associates, Inc., 2002). No threatened or endangered mussel species were found. $E$. complanata was the most abundant and dominant species present (table 1). Because the entire section of river was qualitatively searched only on the surface, it cannot be said with 100 percent certainty that no threatened or endangered species are present; it is possible (although unlikely) that subsurface individuals could have been missed. For example, Smith and others (2001) found that several mussel species had low detectability in surface surveys. Although qualitative sampling generally offers better detection of rare species than quantitative surveys, qualitative surveys are biased towards finding surface-dwelling, large, and sculptured species (Miller and Payne, 1993; Vaughn and others, 1997). Unfortunately, both $A$. heterodon and $A$. varicosa are extremely small, decreasing their detection probability in qualitative surveys. 

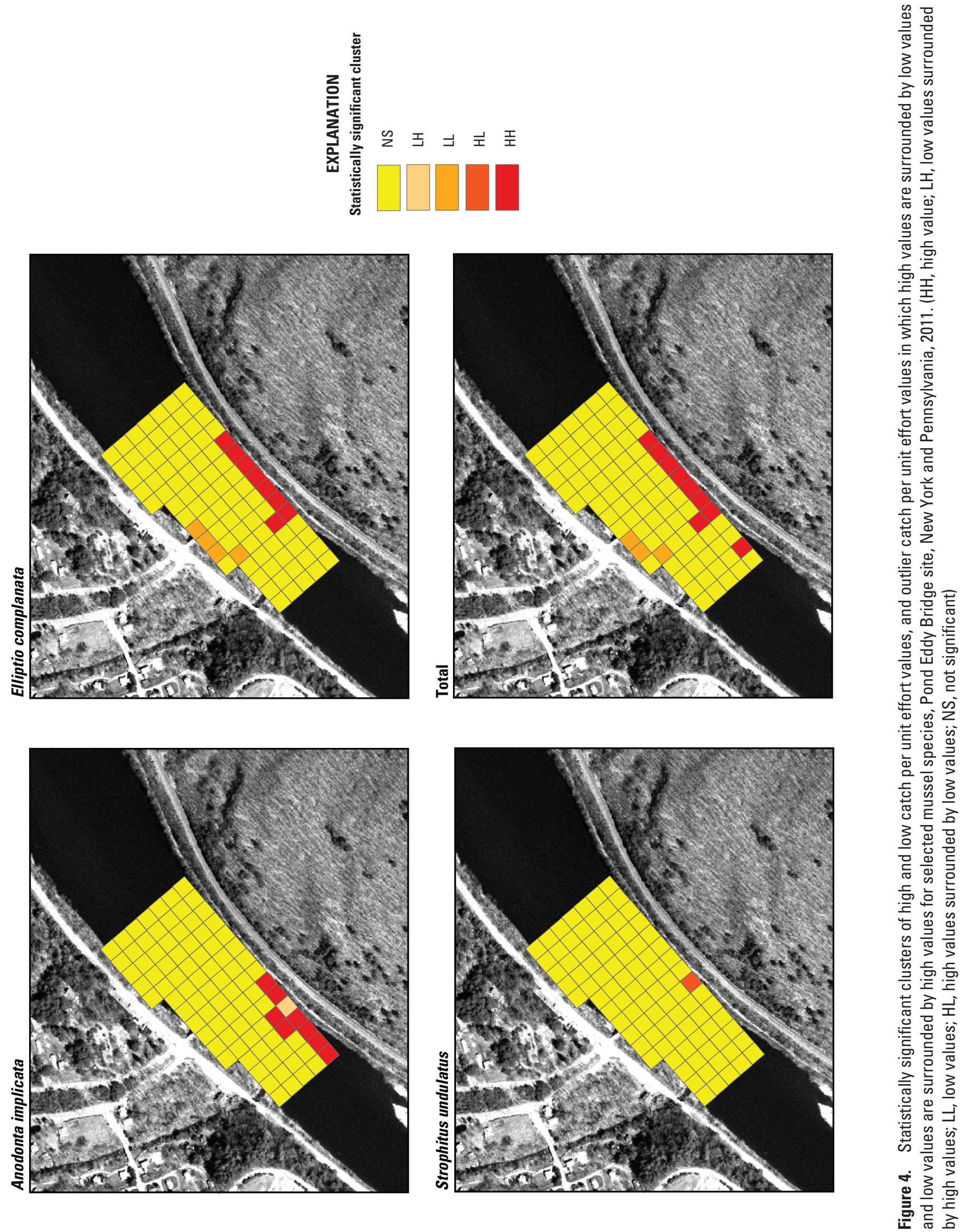

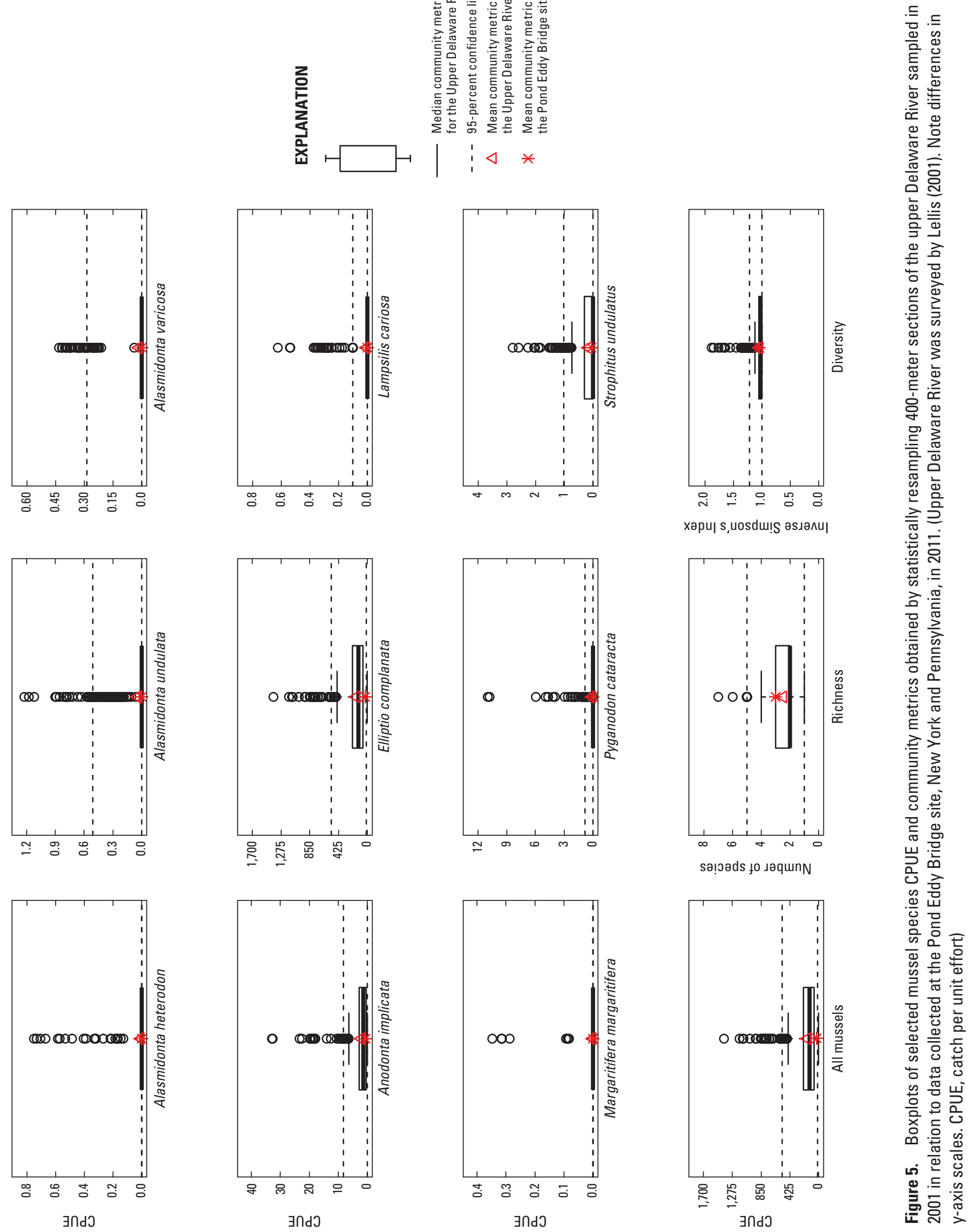

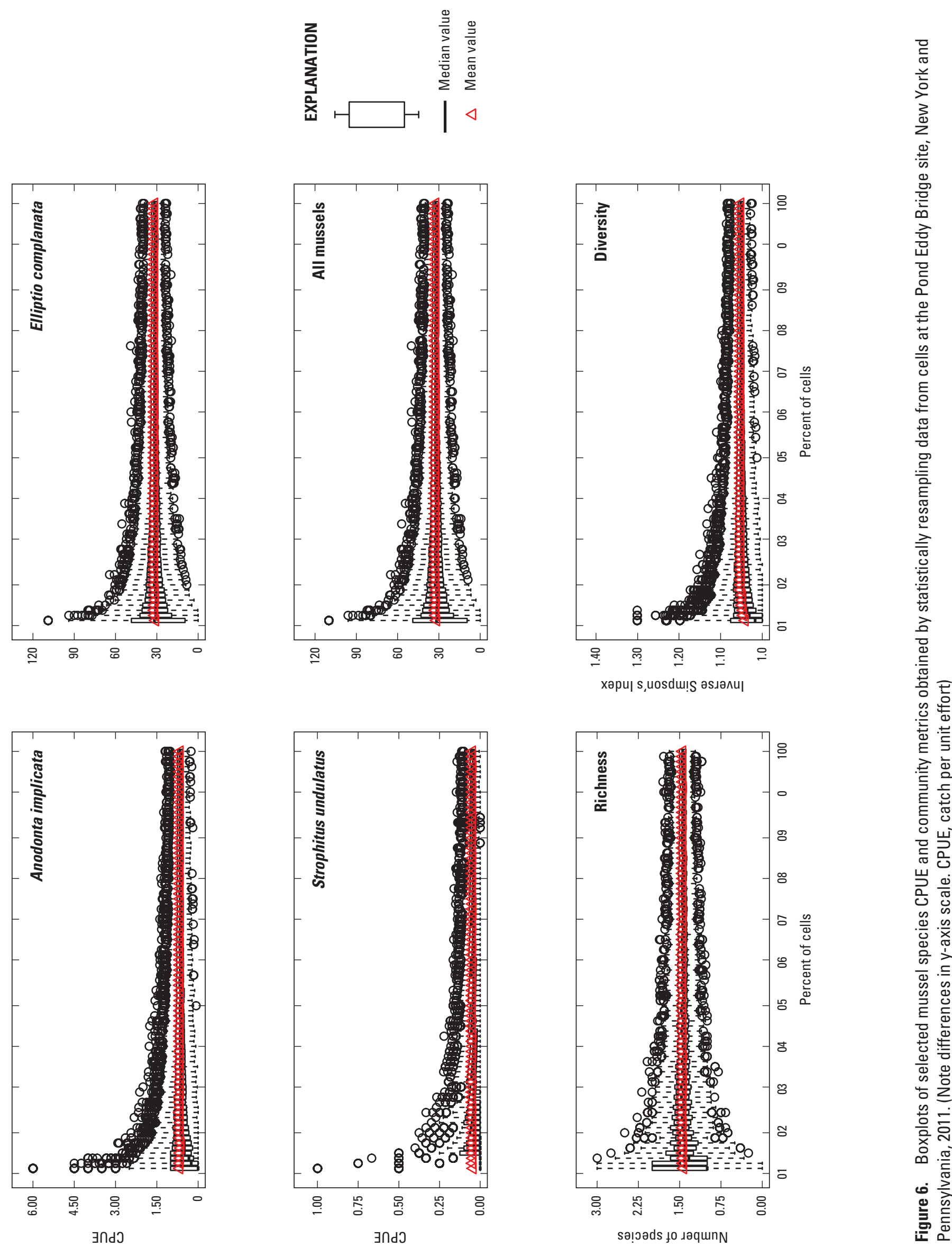

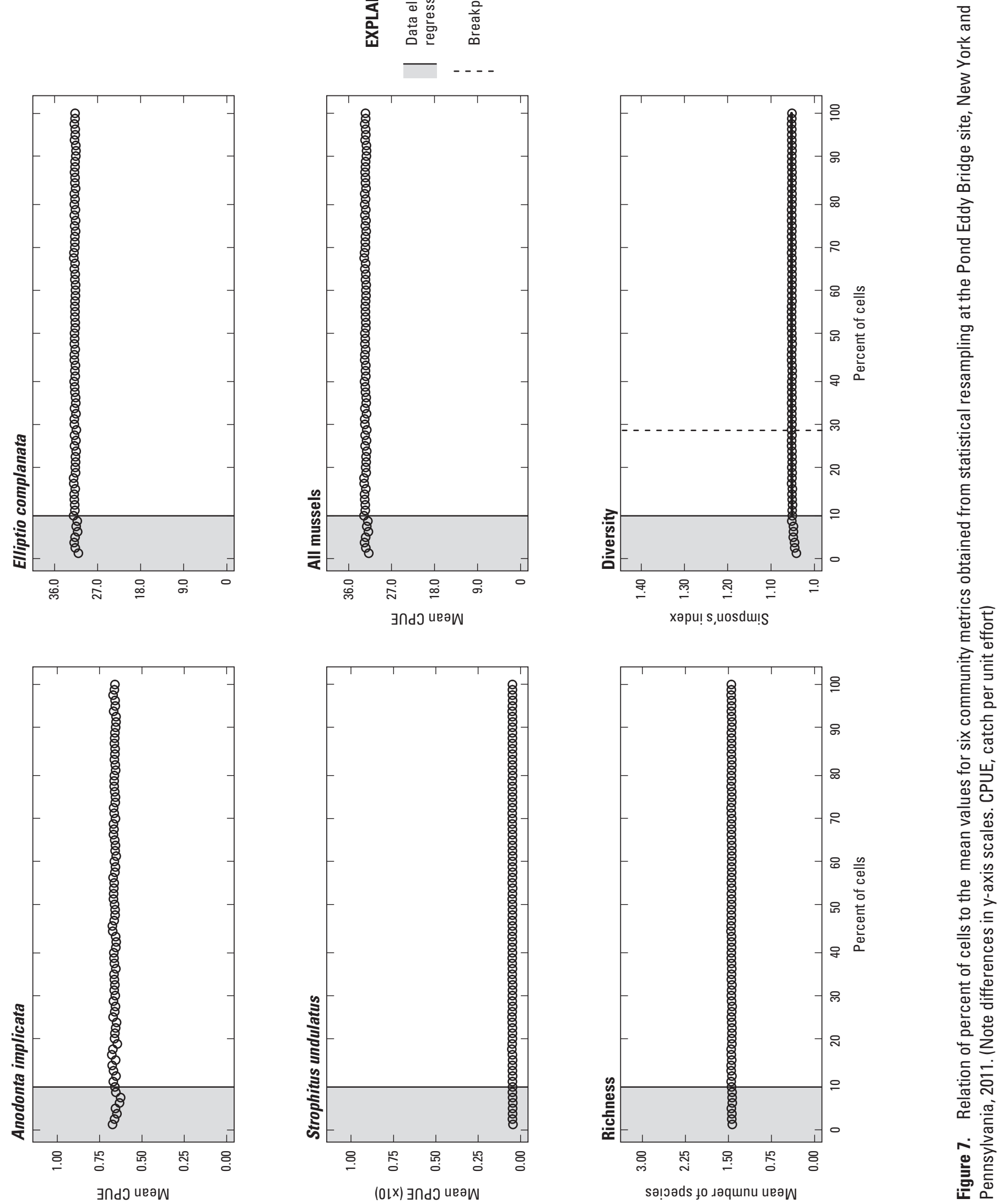

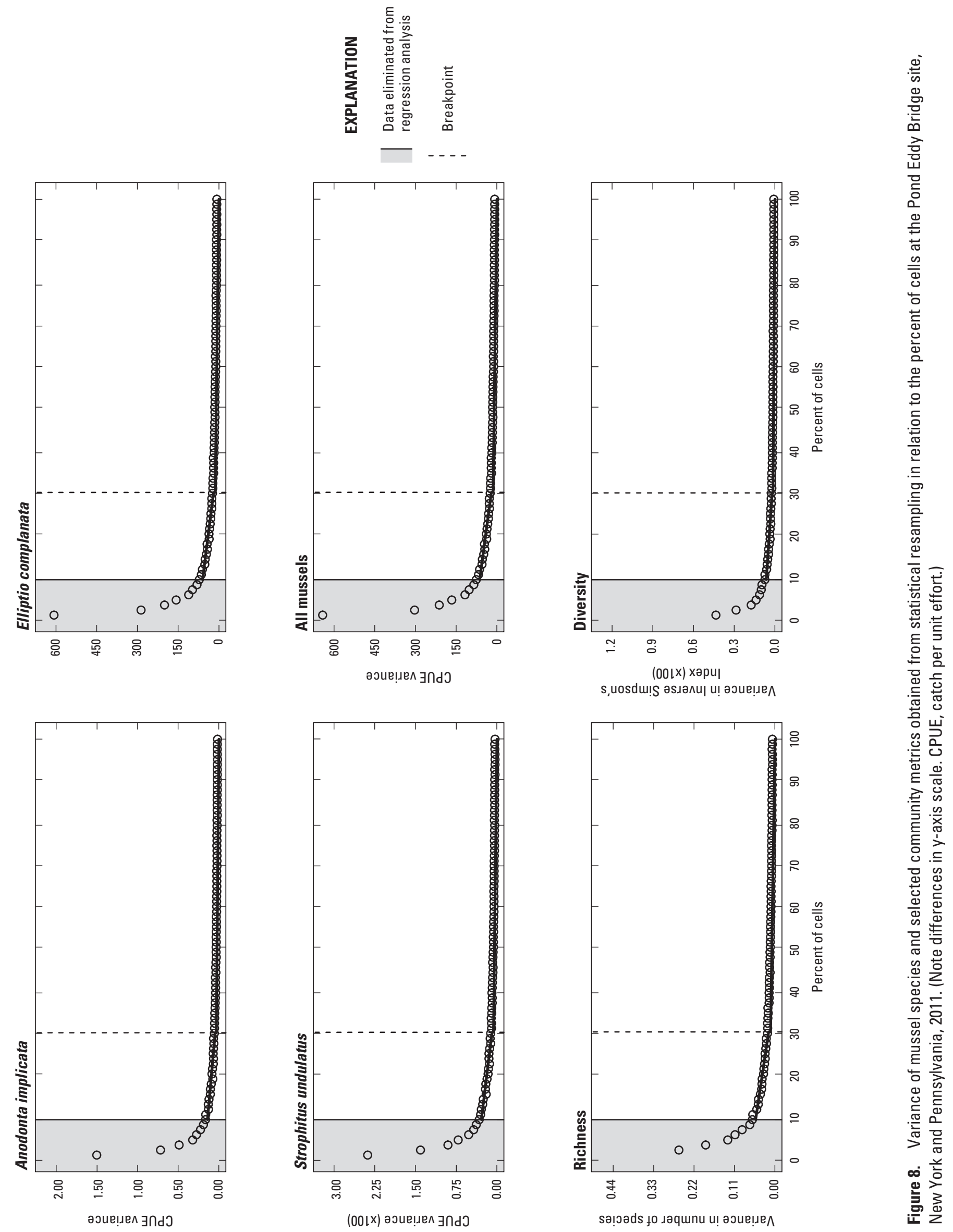
Table 2. Results of linear and segmented regression analysis on community metrics generated from statistical resampling and calculated at different sampling efforts for the 2011 survey at Pond Eddy Bridge site, New York and Pennsylvania.

[SE, standard error; Seg. 1 slope, regression slope prior to breakpoint; Seg. 2 slope, regression slope after breakpoint; lin., linear; seg. segmented; CPUE, catch per unit effort; *, statistical significance at $\alpha$ less than or equal to 0.05 ; NA, not applicable]

\begin{tabular}{|c|c|c|c|c|c|c|}
\hline Metric & & $\mathbf{R}^{2}$ lin. & $\mathbf{R}^{2} \operatorname{seg}$ & $\begin{array}{l}\text { Breakpoint } \\
\text { (SE) }\end{array}$ & Seg. 1 slope & Seg. 2 slope \\
\hline A. implicata CPUE & Mean & 0.003 & N/A & N/A & N/A & N/A \\
\hline \multirow[t]{2}{*}{ E. complanata CPUE } & Mean & -0.007 & N/A & N/A & N/A & N/A \\
\hline & Variance & $0.711 *$ & $0.978^{*}$ & $25.19(0.50)$ & $-2.37 \times 10^{+00}$ & $-2.36 \times 10^{-01}$ \\
\hline S. undulatus CPUE & Variance & $0.701 *$ & $0.975^{*}$ & $25.21(0.52)$ & $-1.14 \times 10^{-04}$ & $-1.09 \times 10^{-05}$ \\
\hline \multirow[t]{2}{*}{ Total CPUE } & Mean & 0.007 & N/A & N/A & N/A & N/A \\
\hline & Variance & $0.711^{*}$ & $0.978^{*}$ & $25.21(0.49)$ & $-2.50 \times 10^{+00}$ & $-2.49 \times 10^{-01}$ \\
\hline Richness & Mean & -0.012 & N/A & N/A & N/A & N/A \\
\hline Diversity & Variance & $0.700^{*}$ & $0.963^{*}$ & $25.10(0.63)$ & $-2.52 \times 10^{-05}$ & $-2.50 \times 10^{-06}$ \\
\hline
\end{tabular}

The likelihood of not detecting threatened or endangered species at Pond Eddy is small based on several factors. First, this site was surveyed by three separate crews on three different occasions with no $A$. heterodon or $A$. varicosa collected. In extensive qualitative surveys of the upper Delaware River by Lellis (2001), both of these and other rare species were detected with substantially less search time (mean \pm standard error $(\mathrm{SE})=1.67 \mathrm{hr} \pm 0.04$ in a 200 -m section of river). If threatened or endangered species were present at the Pond Eddy Bridge site, the greater than 125 hours of survey effort invested in the 2011 study should have been enough to detect them. Second, anecdotal evidence (Lellis and others, 2008) indicates that habitat at the Pond Eddy Bridge site is suboptimal for at least $A$. heterodon. In the historical Delaware River surveys, $A$. heterodon was most often found in sandy shoals, habitat that was essentially nonexistent at Pond Eddy: the predominant substrate type was large boulders. Less is known about $A$. varicosa's habitat preference. Third, given the long life span and limited colonization opportunities for freshwater mussels in general, chances are low that a rare mussel species would have colonized this site since the early 2000s and established a stable, detectable population. If any new species outside of those identified during the 2000s were found at the Pond Eddy Bridge site, they likely would have been transients that were deposited during a spate (Hastie and others, 2001).

Conditions overall at the Pond Eddy site did not appear to be ideal even for common mussel species. Little substrate was present that is suitable for burrowing or moving in general, and mussels often were found trapped between or under large boulders where they probably were deposited. That said, in comparison to the entire upper Delaware River, Pond Eddy's mussel community did fall between the 95 percent confidence limits for all community metrics (fig. 5); however, the metrics were on the low end of the distribution, falling either on or below the mean. The only metric in which the Pond Eddy Bridge site fell above the average for the upper Delaware River was species richness.

A. implicata, although not on Federal or state lists of endangered or threatened species in Pennsylvania or New York, nor a species of special concern (having regulatory protections) in New York, is considered critically imperiled in New York. Analysis of spatial structuring indicated that the highest clustering of $A$. implicata can be found on the Pennsylvania side of the river upstream from the current Pond Eddy Bridge (fig. 4). On the basis of the tentative construction plans, approximately 14 percent of the $A$. implicata at this site are at risk (fig. 9), along with 15 percent and 18 percent of $E$. complanata and $S$. undulatus, respectively. On the other hand, the area upstream from the bridge, extending $50 \mathrm{~m}$ from the bank along the Pennsylvania side contained almost 65 percent of all A. implicata found (fig. 2). Although only a small portion of this stretch is included in the "direct-effects area," the entire upstream reach along the Pennsylvania bank would likely be considered a target for minimization and conservation efforts to protect $A$. implicata.

Similarities among the three surveys conducted at the Pond Eddy site varied according to community metric (table 1). Results of all three studies are similar for the percent species composition and to some extent diversity and richness. The largest discrepancies were evident in the estimates of 


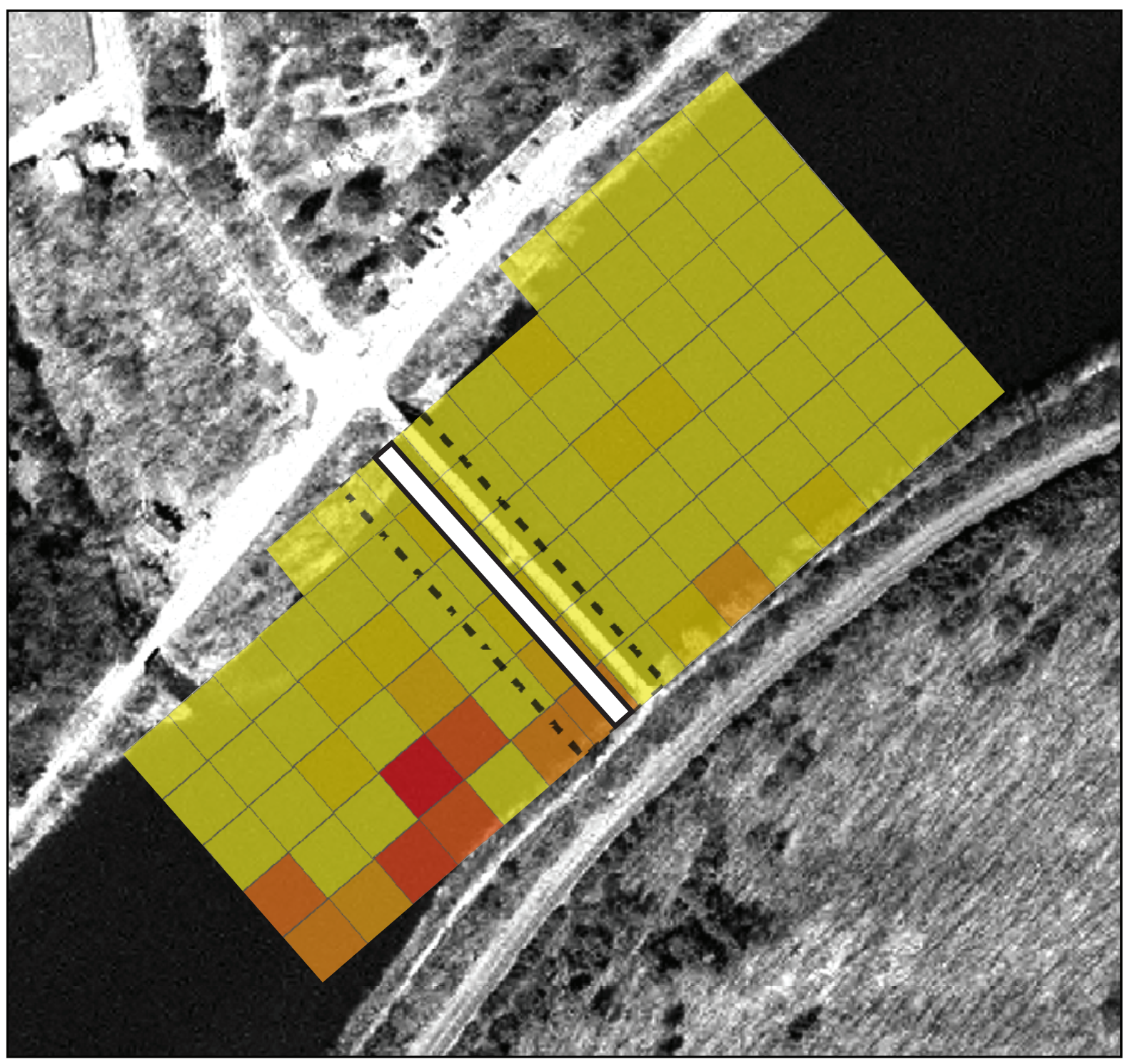

\section{EXPLANATION}

Anodonta implicata, CPUE
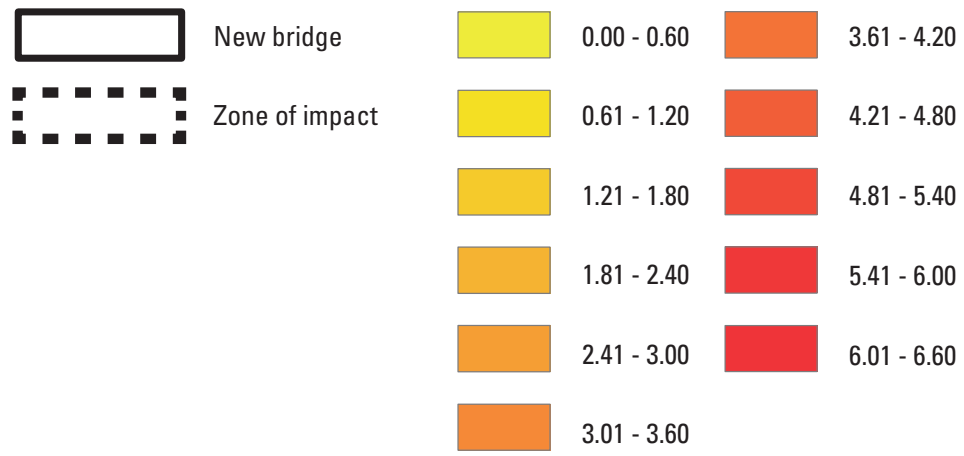

Figure 9. Estimated zone of impact of new bridge construction and mussel Anodonta implicata, in catch per unit effort, at the Pond Eddy Bridge site, New York and Pennsylvania, 2011. (CPUE, catch per unit effort) 
CPUE. Lellis (2001) had consistently higher CPUE estimates, and Normandeau Associates, Inc., (2002) had consistently lower CPUE estimates than those reported for the present study.

Given the differences in the survey techniques used by Lellis (2001) and the present survey, differences in estimated CPUEs are not surprising. The transect method allows surveyors to maximize the time spent surveying suitable mussel habitat and, therefore, is biased towards finding more individuals in a shorter period of time. In the 2011 survey, surveyors were constrained to equally search all habitats, even marginal habitats, which decreased the number of individuals collected per hour of search effort. Differences in CPUEs may also be attributable to mussel community changes over time which can happen relatively quickly (Galbraith and others, 2010), but given the different survey methods, these factors cannot be teased apart.

The differences between the 2011 survey results and those of Normandeau (Normandeau Associates, Inc., 2002) are somewhat surprising, given the overlap in survey methods and location. Normandeau surveyed a slightly smaller area (approximately 5\% less than the area surveyed in 2011); however, even after accounting for this difference there is still a discrepancy in the number of mussels collected, the CPUE, and the lack of $S$. undulatus detected. Recruitment by reproduction is an unlikely explanation (see above). Perhaps these differences could be explained by a large colonization event: upstream populations may have been washed downstream and deposited at the Pond Eddy site during a flood. High flows, such as those experienced in the Delaware River in the mid 2000s, are known to affect mussel distribution (Hastie and others, 2001). Although Hastie and others (2001) observed primarily mortality and mussel loss under catastrophic flood events, there were sites in which mussel communities remained unchanged or in which densities increased. Nonetheless, these results imply that standardizing survey methodology may not necessarily lead to comparable survey results. Caution is needed when interpreting these data because the surveys were completed 10 years apart.

Results of resampling analysis indicate that in order to estimate the community metrics of a typical site (that is, Pond Eddy) in the upper Delaware River, a minimum of approximately 25 cells need to be surveyed (fig. 8). Although surveying fewer cells may approximate the mean community metric, the variance is substantially higher (there is a higher probability of over- or underestimating the metric of interest). Results of segmented regression indicate that for a survey size of greater than 25 cells (an area corresponding to $15,625 \mathrm{~m}^{2}$ or approximately $27 \%$ of the site), the variance levels off such that there are no further dramatic drops in variance (fig. 8). Although increasing the survey effort further decreases variance (as indicated by the negative slopes of the segmented regression lines; table 2), the slopes for most of the metrics are negligible (table 2; fig. 8). In other words, further sampling efforts result in only a marginal decrease in variance. An a priori notion of the minimum sampling effort necessary to assess community composition provides efficient, costeffective sampling. This approach is less applicable, although perhaps adaptable, to construction surveys for endangered species when the goal is to assess the entire river stretch to assure no incidental take occurs. This strategy, however, may be transferrable to basic studies of mussels in the Delaware River.

The methods of the present study have several shortcomings to be considered before designing a sampling methodology for the upper Delaware River. First, this kind of high-resolution $(25 \mathrm{~m} \mathrm{x} 25 \mathrm{~m})$ data are available only for a single site. Additional studies using similar sampling methods to those presented here for several sites in the Delaware River would be useful to confirm the results of this study. Second, estimates of relative abundance (percent species composition here) using qualitative surveys alone have been shown to be biased in the Allegheny River (Smith and others, 2001). Whether or not this is true in the relatively species poor upper Delaware River remains to be assessed. Third, resampling was not conducted in a spatially explicit manner (spatial structuring in the mussel distribution was not considered). Thus, the point in the river where samples are collected could affect the number of cells necessary to assess the community metric of interest. Smith and others (2003) allude to the potential importance of adaptive cluster sampling as an efficient mussel survey technique but found problems using this method in low-density mussel communities. Therefore, further studies that include spatial clustering are needed before the technique is incorporated into mussel survey methods.

Despite its flaws, this study provides preliminary data on the qualitative sampling methodologies necessary for assessing mussel community structure in the Delaware River. Although other studies have examined different sampling methodologies for mussels, many have focused on rivers with high species richness and high evenness (Miller and Payne, 1993; Vaughn and others, 1997; Smith and others, 2001), characteristics unlike those in the upper Delaware River. Whether or not these sampling schemes are relevant in such a system warrants further investigation. This report also alludes to potential discrepancies between and within different survey methodologies. These differences need to be further assessed before standardized methods in mussel survey techniques are adopted. Finally, this study confirms the absence of threatened or endangered mussels in the vicinity of the Pond Eddy Bridge site.

\section{Summary}

This report documents results of a qualitative mussel survey completed in 2011 at the Pond Eddy Bridge spanning New York and Pennsylvania. Mussel data from the 2011 survey are compared to data from two similar surveys completed in the early 2000s. In general, the results from 2011 are comparable to those from the early 2000s in that no mussel species on Federal or state threatened or endangered species lists were 
found at the site. The relative abundance of each of three species-E. complanata, A. implicata, and S. undulatus - was similar among studies, but catch per unit effort (CPUE) varied considerably depending on survey methodology. Discrepancies in CPUE and species richness were found between 2001 and 2011 surveys despite the use of identical survey methodologies. These differences may be attributable to changes in mussel communities over the last 10 years.

A statistical resampling analysis was completed on the 2011 survey data to determine the sampling effort necessary to quantify key community metrics (CPUE of each species, richness, and diversity) at a "typical" mussel location in the Delaware River. Segmented regression output indicates that surveys of approximately 30 percent of a site in the Delaware River may provide a reasonable estimate of community metrics within a site; however, increased sampling effort decreased variance in all of the metrics. These results likely will be useful in designing cost-effective studies of the river in the future, but caution is warranted given that these results are based on a single site in the river.

\section{References Cited}

Anselin, L., 1995, Local Indicators of Spatial AssociationLISA: Geographical Analysis, v. 27, p. 93-115.

Dorazio, R.M., 1999, Design-based and model-based inference in surveys of freshwater mollusks: Journal of the North American Benthological Society, v. 18, p. 118-131.

Efron, B., 1979, Bootstrap methods: Another look at the jackknife: The Annals of Statistics, v. 7, p. 1-26.

Galbraith, H.S., Spooner, D.E., and Vaughn, C.C., 2010, Synergistic effects of regional climate patterns and local water management on freshwater mussel communities: Biological Conservation, v. 143, p. 1175-1183.

Hastie, L.C., Boon, P.J., Young, M.R., and Way, S., 2001, The effects of a major flood on an endangered freshwater mussel population: Biological Conservation, v. 98, p. 107-115.

Hill, M.O., 1973, Diversity and evenness: A unifying notation and its consequences: Ecology, v. 54, p. 427-432.

Huang, Jian, Cao, Yong, and Cummings, K.W., 2011, Assessing sampling adequacy of mussel diversity surveys in wadeable Illinois streams: Journal of the North American Benthological Society, v. 30, p, 923-934.

Lellis, W.A., 2001, Freshwater mussel survey of the upper Delaware Scenic and Recreational River, qualitative survey 2000: Report to the National Park Service, February 20, 2001.
Lellis, W.A., 2002, Freshwater mussel survey of the Delaware Water Gap National Recreation Area, qualitative survey 2001: Report to the National Park Service, March 2, 2002.

Lellis, W.A., Cole, J.C., and Campbell, C.A., 2008, Freshwater mussel survey of the Delaware Water Gap National Recreation Area. Flat Brook qualitative survey 2006-07. Report to the National Park Service, 38 p.

Lydeard, C., Cowie, R.H., Ponder, W.F., Bogan, A.E., Bouchet, P., Clark, S.A., Cummings, K.W., Frest, T.J., Gargominy, O., Herbert, D.G., Hershler, R., Perez, K.E., Roth, B., Seddon, M., Strong, E.E., and Thompson, F.G., 2004, The global decline of nonmarine mollusks: BioScience, v. 54, p. 321-330.

Miller, A.C., and Payne, B.S., 1993, Qualitative versus quantitative sampling to evaluate population and community characteristics at a large-river mussel bed: American Midland Naturalist, v. 130, p. 133-145.

Neves, R.J., Bogan, A.E., Williams, J.D., Ahlstedt, S.A., and Hartfield, P.W., 1997, Status of aquatic mollusks in the southeastern United States: A downward spiral of diversity, in Benz, G.W., and Collins, D.E., eds., Aquatic fauna in peril: The southeastern perspective: Decatur Georgia, Southeast Aquatic Research Institute, Lenz Design and Communications.

Normandeau Associates, Inc., 2002, Phase I survey for dwarf wedge mussels (Alasmidonta heterodon) in the Delaware River near Pond Eddy Bridge: Bedford, N.H., Normandeau Associates, Inc.

Ortmann, A.E., 1919, A monograph of the naiades of Pennsylvania, Part III, Systematic account of genera and species: Memoirs of the Carnegie Museum, v. 8, p. 1-384.

R Development Core Team, 2011, R: A language and environment for statistical computing, accessed March 18, 2011, at http://www.R-project.org/.

Smith, D.R., Villella, R.F., and Lemarie, D.P., 2001, Survey protocol for assessment of endangered freshwater mussels in the Allegheny River, Pennsylvania: Journal of the North American Benthological Society, v. 20, p. 118-132.

Smith, D.R., Villella, R.F., and Lemarie, D.P., 2003, Application of adaptive cluster sampling to low-density populations of freshwater mussels: Environmental and Ecological Statistics, v. 10, p. 7-15.

Strayer, D.L., 1999, Effects of alien species on freshwater mollusks in North America: Journal of the North American Benthological Society, v. 18, p. 74-98.

Vaughn, C.C., 2010, Biodiversity losses and ecosystem function in freshwaters: Emerging conclusions and research directions: BioScience v. 60, p. 25-35. 
Vaughn, C.C., Taylor, C.M., and Eberhard, K.J., 1997, A comparison of the effectiveness of timed searches vs. quadrat sampling in mussel surveys, in Cummings, K.W., Buchanan, A.C., Mayer, C.A., and Naimo, T.J., eds., Conservation and management of freshwater mussels II: Initatives for the future: Rockland, Ill., Upper Mississippi Conservation Committee, Proceedings of a UMRCC symposium, 16-18 October 1995, St. Louis, Missouri.

Watters, G.T., 2000, Freshwater mussels and water quality: A review of the effects of hydrological and instream habitat alterations: Proceedings of the First Freshwater Mollusk Conservation Society Symposium, v. 1999, p. 261-274.

Williams, J.D., Warren, M.L.J., Cummings, K.W., Harris, J.L., and Neves, R.J., 1993, Conservation status of freshwater mussels of the United States and Canada: Fisheries, v. 18, p. 6-22. 
Prepared by the West Trenton Publishing Service Center

For additional information, write to:

\section{Director}

U.S. Geological Survey

Leetown Science Center

11649 Leetown Road

Keaneysville, West Virginia 25430

or visit our Web site at:

http://my.usgs.gov/leetown/ 
